\title{
Modification Of The Model Problem Solving Learning With The Approach Of Offline in Class X Private SMK Az Zahra Sonomartani
}

\author{
Ade Irwansyah Putra Nasution ${ }^{1)}$, Rohani ${ }^{* 2)}$, Dwi Wulan Tristiana ${ }^{3)}$ \\ 1) Fakultas Keguruan dan Ilmu Pendidikan, Universitas Islam Labuhan Batu, Rantauprapat \\ 2,3) Fakultas Saince dan Teknology, Universitas Labuhan Batu, Rantauprapat
}

\author{
*Corresponding author \\ Email:adeirwansyahputran83@gmail.com
}

\begin{abstract}
This study aims to determine the improvement of learning outcomes of biology students through the Modification of the Model Problem Solving Learning Approach With Offline in class X SMK Swasta Az Zahra Sonomartani. Types of quantitative research through the method of Non-equialent Control Group Design. The population used in this study 1 class i.e. class X Computer Engineering and Networks that learned by a Modification of the Model Problem Solving Learning Approach Offline. Data collection in this study using the test, as well as the technique of data analysis used t-Test. The results of the test shows the average value of the pretest of the 34 students in the class that learned Modification of the Model Problem Solving Learning Approach with Offline namely 46,24 with a standard deviation of 7,897 and on the class that learned Modification of the Model Problem Solving Learning approach with Offline of 34 students from the average value of posttest of 73,56 with a standard deviation of 3,230. Berdasrakan the results of hypothesis testing using independent t-test was calculated using IBM SPSS Stastics Version 20 for windows was obtained tcount $>$ ttable that is $(2,833>1,671)$ so it can be concluded that there is an increase in learning outcomes of biology by using a modification of the model Problem Solving learning approach with offline in class X SMK Swasta Az Zahra Sonomartani.
\end{abstract}

Keywords: Problem Solving, Luring The Results Of The Learning

\section{INTRODUCTION}

Biology is a field of study that is studied by all students from ELEMENTARY to high school. The goal of learning biology in school, namely to understand the concept of biology, explain the relationship between the concept and apply the concept, in luwas, accurate, efficient, and precise, in problem solving, solve problems, communicate ideas with symbols, tables, diagrams, or other media to explain the situation or problem, and attitudes to appreciate the usefulness of biology in life, namely curiosity, attention, and interest in the study of biology, as well as having a confident attitude to be able to solve a problem. Based on the importance and purpose of learning biology, expect the process of learning biology is able to encourage the development of understanding and appreciation of the students to the principles, values, and biological processes. This will pave the way for the growth of the power of reason, think that a logical, systematic, critical, and creative, even the students like to study biology. But, in fact from a variety of fields of study in school, biology is a field of study that are considered scary and difficult by the students. As revealed by Lukman (2017) that although biology is a science that is fundamental, but for most students, or anyone who had ever attended school, biology is something that is scary and very difficult. Many parts of biology is not understood by the students, even the parts that simple though, so in the end the biology is considered as a field of study that difficult and students reluctant to learn it. 
In improving the quality of education there is one approach that must be mastered, namely: the approach of substantial education (content approach). The approach will be tied directly to the quality of education and behavior, which is owned by the students in the school, where the teaching and learning process student-centered (student centered), not sepnuhnya by the teacher (teacher centered). That way students will be original or not artificially sheer. Because it is obtained through the learning process and not only through the transfer of information for granted (Shinta, 2015). In essence, the learning process is one of transformation of knowledge, attitudes and skills with engaging student activities. The involvement of students both physically and mentally to make the experience of learning that will form the understanding of which will be owned by the students to the concept of learning. As an educator professional is expected that the educator is able to select and use learning model in accordance with the subject matter, thus the teacher that will be able to improve student learning outcomes.

When this Corona become the talk of the warm. Covid-19 is a disease that is infectious type of virus is coronavirus, which initially found in China. This Virus can affect anyone, be it infants, children, and adults. With the spread of the infectious disease namely Covid-19 made the local government to close the school, which requires the learning process implemented in an online system. Learning offline is one of the learning process which is carried out without face-to-face between teachers and students but it is done through online using internet network. In the pandemic Covid-19 a teacher should make the learning process have to keep running, even though learning was implemented at home through the internet network. In the pandemic Covid-19 a teacher must be able to design learning with the network utilizing the internet. Based on the circular letter of the Minister of Education and Culture Republic of Indonesia Number 4 of the Year 2020, requires that the systems learning through computer devices (leptop) connected with internet network connection. Expected a teacher can implement the learning together by using the group on social media such as WhatsApp (WA), telegram, instagram, zoom app, or other media as the media expenditure. Thus, a biology teacher is able to make sure their students to participate in learning at the same time, although the condition of different places. One alternative that should be done on learning in the pandemic Covid-19 so that can improve the results of student learning is a learning that gives space to students to find and build the concept so that it can improve student learning outcomes is by using a modification of the model Problem Solving learning approach offline. Modification of the model Problem Solving learning approach offline is one of the innovation learning model that can be used because the approach of problem-based learning aims to train students in critical thinking, creative, active and increase understanding of the material that is taught, and give real experience to the students. The role of the teacher as a facilitator not the transferor of knowledge (Lukman, 2017). Modification of the model pembelajaran Problem Solving with the approach of offline, has the goal to help students develop thinking skills, problem solving, learning a variety of adult roles by engaging them in real experience and being a student of the autonomous self. The results of the observations of the author with the mother Nila Kesuma, S.Pd., a biology teacher at the Private SMK Az Zahra is known that the students still have the learning outcomes of low look with the lack of activity ask, answer, respond and represent the opinions of students, where students are still low to solve a problem that exists, and tried to take a conclusion by induction and deduction is still very less on the process of learning activities in the group WhatsApp (WA). The teacher does not use a variation in teaching where the teacher is still giving tasks and a video from Youtube. A learning process that lasts one direction, students are only given tasks. Based on the above description, it is necessary to do research about : "the Modification of the Model Problem Solving Learning Approach With 
Offline Against the Learning Outcomes of Students in Class X of SMK Swasta Az Zahra Sonomartani academic Year 2020/2021”.

\section{RESEARCH METHODS}

\section{The place and Time of Research}

This research has been conducted in the Private SMK Az Zahra Sonomartani which is located at the Cross Street of the Village Sonomartani Kecamatan Kualuh Hulu Kabupaten Labuhanbatu Utara. The time the research was conducted in the months of August to November 2020.

\section{Population and Study Sample}

The population in this study were students of class X SMK Swasta Az Zahra Sonomartani consisting of 3 classes, namely Class X Business Management, Class X Computer Engineering and Networks as well as Class X Teknik kendaraan Ringan with a student population of 102 people. The sample is determined randomly by using Cluster random sampling. Randomization was done with the Indian way of the 3 classes of $X$, so that diperolehas class $\mathrm{X} \mathrm{Te}$ Kknikkompatan and network with siswakany 34 immense. Itinya this class will serve as a class eksimen that dipelajarnajarnakan model modifasi pembbelajaran problem with the approach Offline.

\section{Research Design}

This research design Non-equivalent Control Group Design. In desein this research, there are one group, then given the prettest to know the initial state of a class $X$ student of Computer Engineering and Networks Private SMK Az Zahra Sonomartani that learned with the model Problem Solving learning approach Offline.

\section{Data Collection Techniques}

Descriptive analysis technique is intended to describe the data the results include the mean, median, mode, variance, standard deviation, minimum value and maximum value of data. The Data is then presented in the form of the frequency distribution table using the rule of Sturges and in the form of a histogram.

\section{The Technique Of The Analysis Of The Inferential}

Test Prerequisites Normality Of The Data

Normality test data is intended to determine the normal failure distribution of research data, that are spread in the population is normal. Normality test is done by testing One KolmogorovSmirnov. Data are expressed normal distribution if the probability or the value of Sig $>0,05$. Homogeneity test data is intended to determine differences in the variance of the data, that is groups that make up samples derived from the same population (the prevalence in the population is homogeneous). Test the homogeneity of the data was done with the test Levene's Test. Data are expressed homogeneous if the probability or the value of Sig $>0,05$.

\section{Hypothesis Test}

After the requirements are met the next peng penguin dilakukanukanpian hypothesis, for data and Habil student learning students in the Analyst with menggandikan trial analisik analisisme Independent. If the results of the analisisisis is moving a significant effect between the given 
class treatment. The Overall Data research analyzed it is denganaman manganakan SPSS 20,0 to the window.

\section{RESULTS AND DISCUSSION}

The Results Of Studying The Biological Modification Of The Model Problem Solving Learning Approach Offline.

Students who learned by using a modification of the model problem solving learning approach with offline to obtain the average learning outcomes of biology students is better when viewed from prior learning. In this case the average results of the study on the pretest and posttest can be seen as follows :

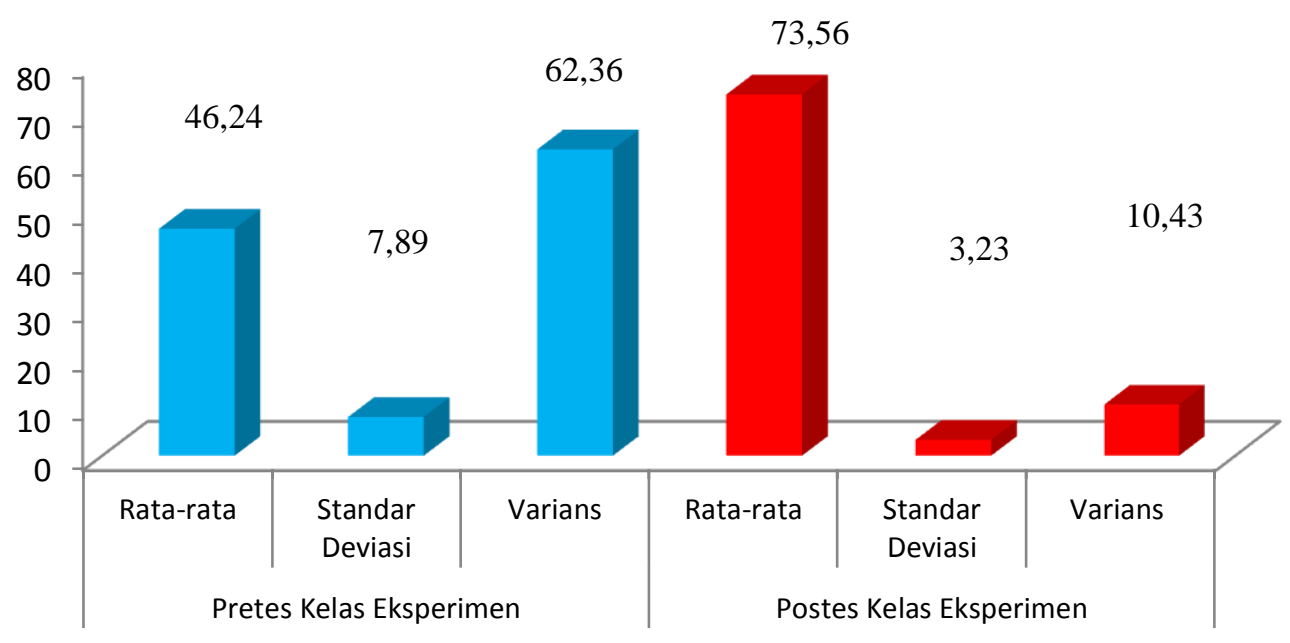

figure 1. Score Data Pretest and Posttes

Based on the Pretest results in figure 1 for a class that taught the modification of the model problem solving learning approach offline with the number of students 34 obtained an average value of 46,24 with a standard deviation of 7,987 and variance 62,367, the highest score of 56 and the lowest score of 30 . While the results of the Posttest after doing learning with the number of students 34 obtained average 73,56 with a standard deviation of 3,230 and variance 10,436 , the highest value is 78 and the lowest value of 70 .

\section{Normality Test Data}

The test used to determine the normal or the presence or absence of data in this research, namely the Kolmogorov-Smirnov with IBM SPSS Stastics Version 20 for windows (with a significant level $\alpha=0.05$ ). The results of the Normality Test shows that from the both groups of students as the research sample has a distribution of data normal distribution on the level of $\alpha=0.05$ is known that the significant value of Asymp.Sig.(2-tailed) $0,132>0,05$. Then in accordance with the basic pengabilan decision in a test of normality kolmogorov-smirnov above, it can be concluded that the normal distribution of data.

Homogeneity Test

To determine the homogeneity of the data in this study using IBM SPSS Stastics Version 20 for windows by using the calculation of the One-Way Annova with a significant level of 0.05. 
Following the results of the homogeneity test that the significant value (Sig) Based on the Mean is of $0.168>0.05$, so it can be concluded that the variance of group Pretest and Posttest class that learned Modification of the Model Problem Solving Learning Approach Offline is the same or Homogeneous.

\section{The Results Of Hypothesis Testing}

Testing in this study using t-test Independent. Hypothesis testing is done to test the presence or absence of an improvement in learning outcomes of biology students who learned with the Modification of the Model Problem Solving Learning Approach Offline. The results of hypothesis testing on the post-test data obtained value of $t(t)$ is equal to 2,833 . The value of $\mathrm{df}$ (degree of freedom) or degrees of freedom is equal to 66. Sig. (2-tailed) or the value of significance to test the two sides is equal to $2,833>1,947$, it can be concluded that $\mathrm{Ha}$ is accepted and Ho is rejected. This means that there is an improvement in learning outcomes of biology that learned Modification of the Model Problem Solving Learning Approach with Offline in class X Computer Engineering and Networks Private SMK Az Zahra Sonomartani.

\section{Discussion}

From the results of data analysis pretest in the experimental group (Class taught modification of the model problem solving learning approach with offline). The results of the calculations show that the average student learning outcomes in the experimental class 46,24 with a standard deviation of 7,897 .

The results of the data analysis of the posttest in the experimental group (Class taught modification of the model problem solving learning approach offline) where the average learning outcomes of the experimental class students of 73,56 with a standard deviation of 3,230 . As well as the well known results of the hypothesis test, namely the value of tcount $>$ ttable $(2,833>1,671)$ with a level of sig 0,05 . This proves the Ho is rejected and Ha is accepted, meaning that there is an increase in learning outcomes of biology students with a modification of the model problem solving learning approach with offline against the learning outcomes of biology students of class X SMK Swasta Az Zahra Sonomartani academic Year 2020/2021.

The experimental class students learn by using a modification of the model problem solving learning approach offline. Stages of learning the modification of the model problem solving learning approach with offline requires students to take an active role in the learning process. This is because the setting of learning that gives students the chance to discuss with friends a bunch of those to resolve the problems that provided the teacher. Modification of the model problem solving learning approach with offline capable of developing creativity and thinking skills of the students in the learning process (Garrett, 2015).

Modification of the model problem solving learning approach with offline exposes students to the problems then students identify the problem and then formulate the problem and determine the hypothesis. The next stage of finding the solution of the problem by collecting the information from various sources and the data obtained and evaluated. The stage of learning that requires students to be more active in the learning process and be able to develop thinking skills as well as competencies that students have so as to improve learning outcomes (Sagala, 2018).

Modification of the model problem solving learning approach with offline able to make the students to be able to actively learn and develop knowledge so as to improve student learning outcomes in the field of biology with the subject matter of the ecosystem. Learning is able to solve problems related to everyday life, so that students are able to associate the initial knowledge possessed by the lessons that students learn in the classroom. The learning process will be more meaningful because the students never find out the problem. Modification of the 
model problem solving learning approach offline so as to improve the skills of problem solving, it is easy to remember and understand, improve the relevant knowledge, encourage students to think, build leadership, and collaboration, skills learning and motivate students. The Student center is the traits learning the modification of the model problem solving learning approach with offline where students role to find the problem, formulate the problem, gather facts, make alternative questions and resolve problems (Rusmono, 2016).

\section{CONCLUSION}

The results of the judging shows that the achievement of learning outcomes as biolgi students of the experimental class obtained an average very good. This can be seen when the assignment takes place, students are actively involved in the learning process. the results showed that there is an increase in learning outcomes of biology students by using a modification of the model problem solving learning approach offline

\section{REFERENCES}

Anna Sylvia. E. Ibrahim, Suyuti \& Lukman Nadjamuddin, (2017). Pengaruh Model Problem Solvig Terhadap Hasil Belajar Mata Pelajaran Ekonomi Pada Siswa SMA Negeri 1 Palu. Jurnal :Vol. 5 No. 4. Hal: 2302-2019.

Arikunto. (2002). Statistik Penelitian Pendidikan, edisi revisi II, Jakarta: Penerbit PT. Rineka Cipta Karya.

(2006). Statistik Penelitian Pendidikan, edisi revisi II, Jakarta: Penerbit PT. Rineka Cipta Karya.

Djamarah, (2010), Strategi Belajar Mengajar, Jakarta: Penerbit Rineka Cipta Karya.

Dimyanti. (2009), Belajar dan Hasil Pembelajaran. Bandung: Penerbit Pustaka Cipta.

Gulo.(2012). Teori Kpribadian. Jakarta: Mandar Maju.

Hamalik, Oemar. (2010). Perencanaan Pengajaran Berdasarkan Pendekatan Sistem. Jakarta: Bumi Aksara.

Nasution, (2010), Penilaian Pembelajaran. Jakarta: Penerbit Bumi Aksara.

Masyhuri, Albertus Djoko Lesmono, \& Rifati Dina Handayani, (2017). Model Problem Solving Disertai Tugas Dalam Pembelajaran Fisika Di SMA (Pokok Bahasan Listrik Dinamis). Jurnal :Vol. 6. No. 4. Hal : 418-426.

Noor. (2011). Strategi Pembelajaran Biologi: Teori, Praktik, dan Penelitian. Padang: UNP Press.

Shinta Anggraini, Syaiful M, \& M. Basri. (2015). Pengaruh Model Problem Solving Terhadap Hasil Belajar Siswa SMA Negeri1 Way Tenong. Jurnal : Fakultas Keguruan dan Ilmu Pendidikan Unila Bandar Lampung. 